\title{
PENGARUH AGAMA ISLAM DALAM JUALBELI MASYARAKAT MELAYU ROKAN DI PROPINSI RIAU
}

\author{
Samariadi \\ Universitas Riau, Email: samariadi@lecturer.unri.ac.id \\ Firdaus \\ Universitas Riau, firdaus@lecturer.unri.ac.id
}

\begin{abstract}
The purpose of this study was to determine the influence of Islam in the selling and buying activities of the Malay Rokan community in Riau Province. The study discussed includes Malay customary law associated with sale and purchase agreements carried out by the Malay Rokan community who are influenced by Islam. The author uses the empirical juridical research method by trying to find legal facts in accordance with what happens as these facts. The results of the research that the authors conclude, namely the finding of the relationship between the influence of Islam in the Malay community in selling and buying is a crystallization of Islamic values that have long been an integral part of the identity of Malay children and keep sharia in its proper place, namely sharia, and customs are maintained without any disruption from buying and selling activities using a sale and purchase agreement.
\end{abstract}

Keywords: Melayu Rokan; Sale and Purchase Agreement; Sharia

\section{Abstrak}

Tujuan penelitian ini untuk mengetahui pengaruh agama Islam dalam aktivitas jualbeli masyarakat melayu rokan di Propinsi Riau. Kajian yang dibahas meliputi hukum adat melayu dikaitkan dengan perjanjian jualbeli yang dilaksanakan masyarakat melayu rokan yang dipengaruhi oleh Agama Islam. Penulis menggunakan metode penelitian yuridis empiris dengan berupaya menemukan fakta hukum sesuai dengan yang terjadi apa adanya fakta tersebut. Hasil penelitian yang penulis jadikan simpulan yaitu ditemukannya hubungan pengaruh Agama Islam dalam masyarakat melayu rokan dalam jualbeli merupakan kristalisasi nilai Islam yang telah lama menjadi bagian yang tidak terpisahkan dari identitas anak melayu dan tetap menempatkan syariah di tempat semestinya yaitu syariah, serta adat tetap terjaga tanpa adanya gangguan dari aktivitas jualbeli dengan menggunakan akad jualbeli.

Kata Kunci: Melayu Rokan; Akad Jualbeli; Syariah 


\section{Pendahuluan}

Perdagangan dalam masyarakat melayu merupakan salah satu sendi dalam kehidupan. Bahkan sulit sekali memisahkan kegiatan perdagangan dalam aktivitas sehari-hari masyarakat melayu. Hal ini berkenaan dengan pola masyarakat berusaha dalam memenuhi kebutuhan hariannya baik untuk pribadi, keluarga, bahkan masyarakat luas.

Aktivitas perdagangan yang terjadi selama ini di kalangan masyarakat melayu rokan terdapat suatu kekhassan. Dimana kedudukan ucapan "boli yo" kemudian dijawab dengan "yo jua" yang ditemui penulis di berbagai pasar tradisional masyarakat melayu rokan mengandung makna lebih dari sekedar perdagangan. ${ }^{1}$ Hal ini telah ada sejak lama diketahui oleh masyarakat melayu rokan yang bersifat turun temurun dalam budaya perdagangan. Istilah yang digunakan dalam percakapan jual beli diatas cenderung dikenal dengan istilah akad jual beli. Akad jual beli seperti ini dapat ditemui dalam peradaban agama Islam.

Transaksi bisnis dan perdagangan dalam kacamata Islam menempati posisi terhormat. la tidak sekedar aktivitas yang mengedepankan prinsip-prinsip pemerolehan keuntungan secara maksimal, tetapi juga diikat oleh bingkai hukum dan moral agama di samping lainnya. Demikian pentingnya transaksi bisnis dan perdagangan ini sehingga Rasulullah menempatkannya sebagai pekerjaan yang sangat mulia, sebagaimana beliau kemukakan ketika menjawab pertanyaan salah seorang sahabatnya perihal pekerjaan yang sangat mulia. Beliau menjawab bahwa seorang yang bekerja dengan tangannya sendiri dan setiap jual beli mabrur, karena Allah SWT mencintai seorang mukmin yang mempunyai kepakaran kerja, dan siapa-siapa yang bersusah payah memberikan nafkah kepada keluarganya tak ubahnya laksana seorang mujahid di jalan Allah SWT. ${ }^{2}$ Prinsip dasar perdagangan Islam adalah adanya unsur kebebasan, keridaan dan suka sama suka dalam melakukan transaksi.

Mekanisme suka sama suka sebagai prasyarat untuk mewujudkan keselarasan dan keharmonisan dalam dunia bisnis dan perdagangan menjadi sebuah keharusan dalam Islam. Aspek hukum lainnya yang tak kalah penting adalah legalitas kehalalan barang atau produk yang diperdagangkan, tidak mengandung unsur-unsur MAGHRIB (sinonim dari Maysir, Gharar, Riba dan Bathil.)

Semua bentuk transaksi bisnis di atas dilarang dalam Islam. Hal ini disebabkan ketidakterpenuhan prinsip etika dan hukum halal yang dianjurkan agama dan etika sosial. Karena itu, jaminan kepastian

\footnotetext{
${ }^{1}$ Hasil pengamatan penulis saat mengunjungi pasar tradsional muara rumbai, kecamatan rambah hilir, kabupaten rokan hulu, propinsi riau.

2 Muhammad dan Rahmad Kurniawan, Visi dan Aksi Ekonomi Islam, Malang: Intimedia, 2014. hIm. 37
} 
hukum halal dan terpenuhinya unsur etika dalam transaksi bisnis suatu produk-produk tidaklah hanya dipandang sebagai sebuah wacana konseptual teoritis yang hanya tersimpan rapi dalam kitab-kitab fiqih klasik dan isu agama semata. Namun, hal itu harus siap memberikan proteksi terhadap konsumen muslim dan telah dipahami dan diterima luas dalam tata bisnis global.

Jaminan kepastian hukum halal dalam produk yang diperdagangkan dengan sendirinya telah memenuhi unsur etika. Unsur ini tidak hanya merefleksikan aspek hukum dalam bisnis dan perdagangan dan aspek etika dalam bisnis melainkan juga merefleksi perwujudan tanggung jawab sosial perusahaan terhadap kemaslahatan konsumen. Aspek kehalalan produk yang diperdagangkan pada hakikatnya tidak hanya ditujukan untuk kepentingan konsumen atas barang dan jasa, tetapi juga mengakomodasi kepentingan produsen dalam menawarkan barang dan jasa kepada konsumen yang membutuhkannya. ${ }^{3}$

Jual beli itu dihalalkan, dibenarkan agama, asal memenuhi syarat-syarat yang diperlukan. Demikian hukum ini disepakati para ahli ijma (ulama Mujtahidin) tak ada khilaf padanya. Memang dengan tegastegas al-qur"an menerangkan bahwa menjual itu halal, sedang riba diharamkan. ${ }^{4}$ Sejalan dengan itu dalam jual beli ada persyaratan yang harus dipenuhi, di antaranya salah satu rukun dalam akad (perjanjian) jual beli itu adalah ijab-qabul yaitu ucapan penyerahan hak milik di satu pihak dan ucapan penerimaan di pihak lain.

Adanya ijab-qabul dalam transaksi ini merupakan indikasi adanya rasa suka sama suka dari pihak-pihak yang mengadakan transaksi. Transaksi berlangsung tidak menyimpang dengan hukum Islam antara lain apabila dilakukan dengan rasa suka sama suka yang menjadi kriteria utama dan sahnya suatu transaksi. Namun suka sama suka itu merupakan perasaan yang berada pada bagian dalam diri manusia, yang tidak mungkin diketahui orang lain. Oleh karenanya diperlukan suatu indikasi yang jelas yang menunjukkan adanya perasaan dalam tentang suka sama suka itu. Para ulama terdahulu menetapkan ijabqabul itu sebagai suatu indikasi. ${ }^{5}$ Oleh sebab itu penerapan akad jual beli seperti yang dilakukan masyarakat melayu rokan memiliki suatu identitas perdagangan masyarakat melayu rokan.

Berdasarkan uraian diatas maka perlu dilakukan penelitian terhadap Pengaruh Agama Islam Dalam Jual Beli Masyarakat Melayu Rokan di Propinsi Riau. Hal ini menjadi penting untuk diteliti karena merupakan langkah awal dalam identifikasi pengaruh agama islam dalam adat melayu riau.

${ }^{3}$ Muhammad dan Rahmad Kurniawan, Visi dan Aksi Ekonomi Islam. Malang: Intimedia, 2014. hlm. 52-53

${ }^{4}$ 5T.M Hasbi ash-Shiddiqi, Hukum-hukum Fiqih Islam, Tinjauan Antar Mazhab, Semarang: PT Pustaka Rizki Putra, 2001, Cet ke-2, hlm. 328

${ }^{5}$ Amir Syarifuddin, Garis-garis Besar Fiqh, Bogor: Kencana, 2003. hlm. 195 


\section{Tinjauan Pustaka}

Budaya melayu merupakan budaya warisan dunia yang besar di bumi nusantara. Wilayahnya mencakup hampir secara menyeluruh daerah masyarakat yang berbahasa rumpun melayu di Asia tenggara. Terutama di wilayah kawasan kepulauan-kepulauan yang kini menjadi bagian dari geopolitiknya seperti: Indonesia, Malaysia, Brunei, Tumasik (sekarang Singapura) Filipina, Thailand, sebagian Vietnam, Kamboja dan Taiwan. Hal ini disampaikan oleh Prof. Zainal Kling dari Universitas Malaya, Malaysia saat seminar nasional. Pengertian ini didasarkan pada corak kemiripan bahasa, karena bahasa merupakan satu-satunya bukti sejarah yang masih tersisa dan dapat membuktikan benar atau tidaknya suatu kawasan yang ditempati oleh kelompok-kelompok rumpun Melayu tersebut. (dikutip dari seminar budaya melayu :2010)

Ditemukan dalam fakta sejarah menunjukkan bahwa kebudayaan melayu ialah buah dari hasil pertemuan antara melayu dengan kebudayaan-kebudayaan lain yang mendatangi kawasan nusantara (red. Melayu). Sebelum kedatangan kebudayaan luar, masyarakat Melayu telah menganut sistem kepercayaan animisme dan dinamisme, sistem bercocok tanam, dan mampu membuat peralatan dari logam. Kebudayaan Melayu yang sudah terbentuk tersebut kemudian diperkarya oleh kedatangan kebudayaan besar dunia, yang terdiri dari empat fase, yaitu: kebudayaan India, kebudayaan China, kebudayaan Arab (Timur Tengah), dan kebudayaan Barat. Pertemuan kebudayaan ini dapat berlangsung dengan damai ataupun dengan ketegangan.

Fase pertama adalah pertemuan kebudayaan Melayu dengan kebudayaan India. Hal ini dapat dilihat dari perkembangan agama Hindu-Buddha, sistem pemujaan yang semakin solid, sistem kerajaan, dan bahasa yang berkembang di dunia Melayu.

Fase kedua adalah pertemuan kebudayaan Melayu dengan kebudayaan China, yang dapat dilhat akan pengaruh Konfusianismenya, perdagangan, kerajinan, dan kesenian dalam masyarakat Melayu. Fase ketiga ditandai dengan pertemuan kebudayaan Melayu dengan kebudayaan Asia Barat (Timur Tengah atau Arab) yang berupa agama Islam, sistem kesultanan, baca-tulis, sistem pendidikan, arsitektur, dan sebagainya. Terakhir, fase keempat adalah pertemuan kebudayaan Melayu dengan kebudayaan Barat, seperti: perkembangan agama Kristen-Katholik, sistem pemerintahan, sistem pendidikan, busana, dan arsitektur.

Diantara persentuhan budaya-budaya tersebut kebudayaan dari Asia Barat (Arab) yang berupa agama Islam, merupakan kebudayaan yang paling banyak berpengaruh dan paling dominan. Begitu kuat dan dominannya pengaruh Islam terhadap kebudayaan Melayu tersebut, 
maka beberapa sarjana mengambil kesimpulan bahwa "Dunia Melayu Dunia Islam".

Secara kultural, sintesa kebudayaan Melayu dan Islam dapat lihat dalam ungkapan "Adat bersendi syarak, syarak bersendikan Kitabullah", ungkapan ini biasa dijumpai di daerah-daerah, seperti: Aceh, Minangkabau, Riau, Jambi, Palembang, Banjar, Bugis, Gorontalo, Ternate, dan sebagainya. Bagi mereka, menjadi Melayu adalah menjadi Islam. Sebaliknya, mereka yang keluar dari Islam, sekaligus adalah keluar dari Melayu (Lihat: Mochtar Naim, 2011: 1).

Begitu menarik diskusi dan perdebatan diantara para ahli mengenai tiga masalah pokok, tentang asal kedatangan Islam, waktu datang Islam dan siapa pembawanya. Mengenai tempat asal datangnya Islam di Dunia Melayu atau Asia Tenggara. Sebagai catatan masuknya Islam di alam Melayu bukan dengan peperangan ataupun penjajahan. Islam berkembang dan tersiar justru dengan cara damai serta persuasif berkat kegigihan para ulama, karena memang para ulama berpegang teguh pada prinsip QS al-Baqarah ayat 256: yang artinya" Tidak ada paksaan dalam agama (Q.S al-Baqarah:256)

Adapun cara masuknya Islam di dunia Melayu setidaknya terdapat tiga teori. Pertama, Islam datang langsung dari Arab, atau tepatnya Hadramaut. Teori ini pertama kali dikemukakan Crawfurd (1820), Keyzar (1859), Niemann (1861), dan Veth (1978) Crawfurd menyatakan, Islam datang langsung dari Arab, meskipun demikian ia menyarankan bahwa interaksi penduduk nusantara dengan kaum Muslim yang berasal dari pantai Timur india juga merupakan faktor penting dalam penyebaran Islam di Nusantara.

Sementara itu Keyzar, beranggapan Islam di Nusantara datang dari Mesir atas dasar pertimbangan kesamaan kepemelukan penduduk Muslim di kedua wilayah yang bermazhab Syafi'i. Teori tentang mazhab ini diikuti oleh Niemann sebagai sumber datangnya Islam, sebab Muslim Hadramaut adalah pengikut mazhab Syafi'i seperti seperti juga kaum muslim Nusantara.

Adapun Veth hanya menyebut dibawa "orang-orang Arab" tanpa menunjuk tempat asal mereka. Teori semacam ini juga dikemukakan oleh Hamka dalam seminar Sejarah Masuknya Islam masuknya ke Indonesia tahun 1962. Menurutnya Islam masuk ke Indonesia langsung dari Arab, bukan dari India, buka pula dalam abad ke 11, melainkan abad pertama Hijriah atau VII Masehi.

Dari teori di atas tentang kedatangan Islam di atas, peneliti lebih condong mengikuti teori pertama yang menyatakan bahwa Islam di Dunia Melayu berasal dari tanah Arab, terutama dengan mengajukan beberapa bukti hubungan dunia Melayu dengan Timur tengah.

Dengan bukti-bukti tersebut, ahli sejarah tempatan, seperti Wan Husin Abdul Kadir, Hamka, A. Hasymi, dan Naguin Al- Attas. Mereka berpendapat bahwa kedatangan Islam ke Nusantara buka pada abad ke 13, 14 dan 15, tetapi jauh lebih awal, yaitu pertengahan abad ke 7 . 
Pendapat ini sejalan dengan hasil seminar "sejarah kedatangan Islam ke Indonesia" pada tanggal 17-20 Maret di Medan yang penulis dapat dari beberapa sumber buku Api Sejarah karya Ahmad Mansur Suryanegara.

Islam diterima secara luas oleh masyarakat Melayu karena Islam tidak mengenal sistem kasta dan menjunjung kesetaraan pada sesama manusia, sehingga memungkinkan keterlibatan semua lapisan masyarakat dalam seluruh aspek kehidupan. Islam mempunyai dasar filosofis dan rasional yang kuat, mempengaruhi seluruh kehidupan orang Melayu. Dalam kehidupan sehari-hari Islam menjadi sumber panutan yang penting dan menjadi identitas orang Melayu sejak saat itu.

Jika diltelusuri dari beberapa literatur tentang proses Islamisasi yang dilakukan tokoh Islam untuk menyebarkan agama ini ke Dunia Melayu, banyak ragam dan cara yang dijumpai. Diantaranya:

a. Saluran Tasawuf

Menurut banyak Ahli, antara lain Azyumardi Azra, para sufi pengembaralah yang berhasil mengislamankan sejumlah penduduk besar di Nusantara, setidaknya sejak abad 13. Pada masa itu, tepatnya setelah jatuhnya Baghdad pada 1258M, sufisme menjadi fenomena massal di dunia Islam dan mengalami masa kejayaan. (Azyumardi Azra:1994)

Dengan demikian, proses Islamisasi Nusantara terjadi saat dunia Islam secara keseluruhan berada dalam titik kemunduran, baik dalam bidang politik, ekonomi mapunun intelektual. Oleh karena itu tidak mengherankan jika penyebar Muslim yang datang ke Nusantara sangat diwarnai oleh termterm tasawuf, walaupun tidak mengabaikan aspek syariah sama sekali. Prestasi kelompok sufi didukung beberapa hal, antara lain: Pertama, para sufi berhasil menyuguhkan wajah Islam dalam kemasan yang atraktif, dengan menonjolkan sikap toleran terhadap pemikiran dan praktek tradisional, Kedua, kondisi seperti itu menjadikan Islam "cocok" dengan budaya dan latar belakang masyarakat setempat yang telah lama dipengaruhi aksetisme Hindu Budha dan kepercayaan lokal.

Pengajar-pengajar tasawuf atau para sufi mengajarkan teosofi yang bercampur dengan ajaran yang sudah dikenal luas oleh masyarakat Indonesia. Mereka mahir dalam soal magis dan mempunyai kekuatan-kekuatan menyembuhkan. Diantara mereka juga ada yang menikahi puteri-puteri bangsa setempat. Dengan tasawuf, "bentuk" Islam yang diajarkan kepada penduduk pribumi mempunyai persamaan dengan alam pikiran mererka yang sebelumnya menganut agama Hindu, sehingga agama baru itu mudah dimengerti dan diterima. Diantara ahliahli tasawuf yang memberikan ajaran yang mengandung persamaan dengan alam pikiran Indonesia pra-Islam itu adalah 
Hamzah Fansuri di Aceh, Syekh Lemah Abang, dan Sunan Panggung di Jawa. Ajaran mistik seperti ini masih dikembangkan di abad ke-19 M bahkan di abad ke- $20 \mathrm{M}$ ini. Termasuk di wilayah Kabupaten Rokan Hulu Propinsi Riau.

b. Saluran perkawinan

Dari sudut ekonomi, para pedagang Muslim memiliki status sosial yang lebih baik dari pada kebanyakan pribumi, sehingga penduduk pribumi terutama puteri-puteri bangsawan, tertarik untuk menjadi isteri saudagar-saudagar itu. Sebelum menikah mereka diislamkan terlebih dahulu. Setelah mereka mempunyai keturunan, lingkungan mereka makin luas, akhirnya timbul kampung-kampung, daerah-daerah dan kerajaan Muslim. Dalam perkembangan berikutnya, ada pula wanita Muslim yang dikawini oleh keturunan bangsawan, tentu saja setelah mereka masuk Islam terlebih dahulu, jalur perkawinan ini jauh lebih menguntungkan apabila antara saudagar Muslim dengan anak bangsawan atau anak raja dan anak adipati, karena raja dan adipati atau bangsawan itu kemudian turut mempercepat proses Islamisasi.

Sebagai contoh saja. Masuknya Islam ke Indragiri melalui pantai barat Sumatera dibawa oleh seorang ulama bernama Sayed Ali al- Idrus. Jalur-jalur yang dilaluinya adalah dari Hadramaut singgah di samudera pasai dan sampai di pantai barat Sumatera tapatnya kota Air Bangis. Di daerah ini ia tinggal berapa lama dalam tugas mengembangkan agama Islam, kemudian menuju timur dan sampai ke kerajaan Siak, terus ke Pelalawan. Dari Pelalawan ia meneruskan perjalanan ke arah selatan, tepatnya di Batu Rijal Inderagiri. (Lihat, Pemda Propinsi Riau: Sejarah Kesultanan Inderagiri, Pekanbaru 1994).

c. Saluran perdagangan

Pada taraf permulaan, seperti disinggung di atas, proses masuknya Islam adalah melalui perdagangan. Kesibukan lalulintas perdagangan pada abad ke-7 hingga ke-16 membuat pedagang-pedagang Muslim (Arab, Persia dan India) turut ambil bagian dalam perdagangan dari negeri-negeri bagian Barat, Tenggara dan Timur Benua Asia. Saluran Islamisasi melaui perdagangan ini sangat menguntungkan karena para raja dan bangsawan turut serta dalam kegiatan perdagangan, bahkan mereka menjadi pemilik kapal dan saham.

Mereka berhasil mendirikan masjid dan mendatangkan mullah-mullah dari luar sehingga jumlah mereka menjadi banyak, dan karenanya anak-anak Muslim itu menjadi orang Jawa dan kaya-kaya. Di beberapa tempat penguasa-penguasa Jawa yang menjabat sebagai Bupati Majapahit yang ditempatkan di pesisir Utara Jawa banyak yang masuk Islam, bukan karena hanya faktor politik dalam negeri yang sedang 
goyah, tetapi karena faktor hubungan ekonomi dengan pedagang-pedagang Muslim. Perkembangan selanjutnya mereka kemudian mengambil alih perdagangan dan kekuasaan di tempat-tempat tinggalnya.

d. Saluran pendidikan

Proses Islamisasi juga dilakukan melalui pendidikan, baik pesantren maupun pondok yang diselenggarakan oleh guruguru agama, kiai-kiai dan ulama. Di pesantren atau pondok itu, calon ulama, guru agama dan kiai mendapat pendidikan agama. Setelah keluar dari pesantren, mereka pulang ke kampung masing-masing atau berdakwah ketempat tertentu mengajarkan Islam. Misalnya, pesantren yang didirikan oleh Raden rahmat di Ampel Denta Surabaya, dan Sunan Giri di Giri. Lulusan atau keuaran pesantren ini banyak yang diundang ke Maluku untuk mengajarkan Agama Islam.

e. Saluran kesenian

Saluran Islamisasi melalui kesenian yang paling terkenal adalah pertunjukan wayang. Dikatakan, Sunan Kalijaga adalah tokoh yang paling mahir dalam mementaskan wayang. Dia tidak pernah meminta upah pertunjukan, tetapi ia meminta para penonton untuk mengikutinya mengucapkan kalimat syahadat. Sebagian besar cerita wayang masih dipetik dari cerita Mahabarata dan Ramayana, tetapi dalam cerita itu di sisipkan ajaran nama- nama pahlawan Islam. Kesenian-kesenian lainnya juga dijadikan alat Islamisasi, seperti sastra (hikayat, babad dan sebagainya), seni bangunan dan seni ukir.

f. Saluran politik

Di Maluku dan Sulawesi selatan, kebanyakan rakyat masuk Islam setelah rajanya memeluk Islam terlebih dahulu. Pengaruh politik raja sangat membantu tersebarnya Islam di daerah ini. Di samping itu, baik di Sumatera dan Jawa maupun di Indonesia Bagian Timur, demi kepentingan politik, kerajaankerajaan Islam memerangi kerajaan-kerajaan non Islam. Kemenangan kerajaan Islam secara politis banyak menarik penduduk kerajaan bukan Islam itu masuk Islam (Azra: 1994)

Salah satu strategi politik dalam penyebaran Islam yakni dengan menggunakan bahasa Melayu sehingga mudah diterima masyarakat, dan mampu mengangkat derajat bahasa Melayu dari bahasa pinggiran menjadi bahasa yang mampu membicarakan persoalan ilmiah dan rasional. Keterpautan Islam dengan Melayu secara geografis dan politis adalah hal yang tidak terelakkan sehingga jaringan keislaman di Semenanjung Sumatera dan Jawa memang tergantung dengan dunia Melayu.

Islam menyebar ke Nusantara yang melalui pedagang Gujarat dan Persia melalui Aceh. Kerajaan Samudera Pasai 
menjadi kerajaan pertama yang menganut dan menyebarkan ajaran Islam kepada masyarakat Aceh. Suatu kebanggaan bagi masyarakat Aceh sebagai penerima ajaran Islam pertama di Nusantara, sehingga Aceh dikenal sebagai negeri serambi Mekkah karena begitu mudahnya Islam dapat diterima oleh masyarakat setempat dan penyebarannya begitu pesat.

Sejarah telah membuktikan bahwa masyarakat Melayu pernah mengalami masa gemilang. Perdagangan yang dijalankan masyarakat Melayu mampu merambah berbagai belahan dunia pada masanya. Bahkan pada era Sultan Iskandar Muda berkuasa di Aceh, kerajaan Aceh termasuk dalam lima kerajaan terbesar di dunia. Kerajaan Sriwijaya, Majapahit, Aceh, Malaka, dan Demak tak dapat dipungkiri menjadi tonggak kebesaran rumpun Melayu. Tidak dinafikan bahwa Melayu saat itu memiliki jati diri yang kuat, mampu menyesuaikan diri terhadap perubahan, berdaya tahan tinggi dan berperan aktif dalam kesinambungan kehidupan bangsa.

Namun kegemilangan masyarakat Melayu yang terjadi di masa lampau tidak nyata terlihat di masa sekarang. Perekonomian masyarakat Melayu jauh tertinggal dibandingkan dengan Barat dan China. Kesadaran masyarakat Melayu sebagai saudara serumpun makin berkurang, puak-puak Melayu tercerai berai akibat politik pecah belah pemerintah kolonial, dan masyarakat Melayu termarjinalisasi akibat perkembangan kapitalisasi dan globalisasi. Keunggulan ekonomi yang dibangun dengan semangat keMelayuan dan berteraskan Islam itulah yang menjadi faktor penggerak dan pendorongnya, yang memberi warna baru dan mempercepat terwujudnya sistem dan keunggulan Melayu, sehingga jejak Melayu nampak dimana-mana.

Dengan demikian, penulis sengaja menyajikan secercah kekuatan Islam dalam membangun peradaban dunia Melayu, apabila dicermati dengan seksama, antar Islam dan Melayu merupakan dua mata sisi uang yang saling membutuhkan, satu dengan yang lainnya menyatu dan bersebati dalam kehidupan.

Orang Melayu memandang Islam tidak hanya sebagai sebuah agama pilihan yang diridhoi Allah SWT, tetapi mereka juga memandang Islam sebagai identitas. Pandangan seperti ini terjermin dalam kehidupan orang Melayu sehingga timbul ungkapan bahwa orang Melayu mesti beragama Islam, bila ia tidak Islam berarti ia tidak Melayu. Ini bermakna bahwa Islam menjadi identitas utama bagi orang Melayu seperti dinyatakan dalam ungkapan berikut:

Apa tanda Melayu jati

Bersama Islam hidup dan mati

Apa tanda Melayu jati

Islam melekat di dalam hati 
Islam digambarkan sebagai penanda utama bagi orang Melayu untuk membedakan orang Melayu dengan orang tidak Melayu. Kuatnya identitas Islam dalam diri orang Melayu menyebabkan bahwa Islam tidak bisa dipisahkan dari diri mereka sehingga sampai mati pun Islam menjadi agama orang Melayu. Islam digambarkan benar-benar telah menyatu dalam diri orang Melayu. Dalam ungkapan yang lain dinyatakan pula bahwa tanda "tuah" atau keistemewaan orang Melayu adalah memeluk Islam secara benar:

Apa tanda Melayu bertuah

Memeluk Islam tiada menyalah

Apa tanda Melayu bertuah

Sebarang laku menurut sunnah

Kata "tuah" merupakan suatu ungkapan yang sering digunakan oleh orang Melayu untuk mengidentifikasi diri mereka sebagai kaum yang mempunyai keistimewaan yang diberikan Tuhan seperti memeluk Islam, keagungan kerajaan Melayu, dan sumber daya alam yang melimbah. Perpaduan Islam dan pemikiran orang Melayu menjadikan Islam sebagai panduan utama bagi orang Melayu dalam menjalankan kehidupan.

Identitas sebagai kaum pilihan dikaitkan dengan keteguhan keimanan mereka dalam memeluk Islam. Keimanan menjadi dasar utama bagi orang Melayu menyembah Tuhan agar manusia benarbenar mempercayai ajaran Islam sebagai pedoman dalam kehidupan.

Kemunculan Islam sebagai agama yang memiliki dominasi di kawasan Melayu atau Asia Tenggara telah menarik perhatian para ahli dan mencoba menjelaskan kenapa Islam mampu hadir sebagai agama yang dianut mayoritas terbesar di Nusantara, dengan mengemukakan berbagai teori. Salah satunya seperti dikemukakan A.H. John dan Fatimi, beliau menyebutkan adanya faktor "kesamaan" antara bentuk Islam yang pertama kali datang ke Nusantara dengan sifat mistik dan sinkritis kepercayaan nenek moyang setempat sebagai penyebab Islam cepat diterima dan menjadi dominan. Oleh karena itu, menurut teori ini Islam tasawwuf nyaris secara alami diterima, dan buktinya Islam di Jawa dapat hidup berdampingan dengan kepercayaan nenek moyang di Jawa. Para sufi ini berhasil mengislamkan jumlah besar penduduk Nusantara setidaknya sejak abad ke 12 dan abad ke 13.

Faktor utama keberhasilan konversi adalah kemampuan para sufi menyajikan Islam dalam kemasan yang atraktif, khususnya dengan menekankan kesesuaian dengan Islam, ketimbang perubahan dalam kepercayaan dan praktik keagaaman lokal.

Melihat kondisi seperti itu, tidak mengherankan jika penyebar Muslim yang datang ke Nusantara sangat diwarnai oleh term-term tasawuf, walaupun tidak mengabaikan aspek syariah sama sekali. Prestasti kelompok sufi berhasil menyuguhkan wajah Islam dalam kemasan yang atraktif, dengan menonjokan sikap toleran terhadap pemikiran dan praktek tradisional. Kondisi seperti itu menjadikan Islam 
"cocok" dengan budaya dan latar belakang masyarakat setempat yang telah lama dipengaruhi aksetisme Hindu Budha dan sinkritisme kepercayaan lokal. (Lihat Azyumardi Azra, 1989:22)

Model Islamisasi dalam kecenderungan tasawuf itu secara bertahap diimbangi dengan orientasi syariah. Apabila kita cermati, munculnya gerakan fikih di Nusantara pada abad ke 17 dan 18 adalah merupakan kelanjutan dari orientasi ajaran tasawuf yang sudah terlebih dahulu muncul dan sedemikian kuat memberikan warna Islamisasi kawasan ini.

Menurut A. Jhon, ajaran tasawuf pada awal proses Islamisasi Nusantara pernah memainkan peranan yang amat penting. Pertama, karena para ahli tasawuf dapat menyesuaikan ajaran Islam kepada tingkat kefahaman masyarakat setempat. Kedua, ajaran tasawuf juga tidak kurang daya tariknya. Menerima ajaran tasawuf dan memasuki tarekat berarti memasuki suatu keluarga besar yang saling tolong menolong. Ditambah lagi, banyak anggota tarekat itu merupakan saudagar yang belajar ke seluruh dunia Islam. Itulah sebabnya pada awal abad ke 17, ada empat tarikat yang berkembang luas di Aceh, yaitu tarikat Qadariyah, Naqsabandiyah, Syatariyah dan Rifaiyyah. (Dikutip dalam Liaw Yock Fang, Sejarah Kesusteraan Melayu Klasik Jilid 2, Jakarta, Erlangga, 1993, Hal 7-9.)

Tidak dapat diingkari bahwa sifat risalah-risalah Islam yang bayak terdapat pada Melayu dahulu menggambarkan bahwa sebagian besar dari isinya mengandung unsur-unsur metafisika ilmu tasawuf yang telah mencapai nilai luhur dalam sejarah pemikiran. Ilmu tasawuf sesungguhnya mengikuti pandangan Islam itu sendiri. Jiwa masyarakat Melayu mulai mengalami penghidupan baru dengan mengalirnya unsurunsur Islam dalam nadinya, laksana air raksa menjulang tinggi tersentuh sinaran surya baru.

Para penyebar agama Islam menyebarkan kepercayaan ketuhanan yang tunggal yang kodrat-Nya terhukum pada hikmah- Nya, yang Iradah-Nya berjalan selaras dengan Akal. Manusia dicitakan dengan hasil ciptaan tertinggi, bahwa dalam gelang kehidupan semestaa, manusia adaalah ibarat permatanya. Sifat asasi manusia itu ialah akalnya dan unsur aqliah inilah yang menjadi perhubungan antara Dia dan Hakikat semesta, konsep-konsep seperti inilah, dan konsep yang menjelaskan kesamaan taraf dan nilai anatara sesorang dengan seorang lainnya, yang menganugerahi antar satu dengan yang lainnya.

Islam membawa semangat rasionalisme dan intelektualisme bukan saja di kalangan istana dan keraton, tapi juga sampai merebak di kalangan rakyat jelata. Tuntutan budi dan akal mengenai hal-hal agama, berekenaan keagamaan dan kemurnian batin serta ilmu mengenainya tersebar luas mendalam laksana akar beringin merangkum bumi.

Pengaruh Islam terhadap Peradaban Melayu tidak terlepas oleh sebuah peradaban atau tamadun Melayu, kembali kita lihat arti kata 
"tamadun" yang digunakan untuk menunjukkan "civilization" berasal dari kata 'madana', yaitu kata kerja yang artinya membina atau membuka bandar, membudi perkertikan, memurnikan, melahirkan dan sopan santun. sedangkan melayu adalah berasal dari kata mala (yang berarti mula) dan yu (yang berarti negeri). Ini berarti tamadun melayu itu ialah kota yang yang penuh dengan peradaban.

Menurut Mohd. Koharuddin Mohd. Balwi Peradaban atau tamadun Melayu adalah suatu puncak pencapaian pemikiran dan sejumlah perlakuan yang baik (adab dan adat) termasuk juga segala hasil artifaknya (budaya benda) yang membentuk sebuah masyarakat yang teratur dan mementingkan kesejahteraan sosial untuk menyempurnakan segala sistem kehidupannya (sosial, politik, ekonomi dan keagamaan) Lihat, Mohd Koharudin, 2005:3)

Dengan kata lain, Peradaban Islam melayu dapat dikatakan sebagai suatu daerah dimana terdapat komunitas ras-ras melayu ataupun rumpun-rumpun melayu yang telah maju peradabannya dan kebudayaannya, baik itu di sektor politik atau pemerintahan, teknologi, ekonomi, dan pengolahan di bidang agraris dan maritim, yang tetap menjunjung tinggi nilai-kebudayaan, agama (Islam), Sosial yang mencakup pentauhidan kepada Allah SWT, ahklak dan hubungan antar manusia.

Menurut Muhammad Naquib al-Attas ada beberapa teori tentang kedatangan dan penyebaran Islam di kepulauan Melayu, ini merupakan faktor yang menyebabkan orang Melayu mengidentifikasikan diri dan peradabannya dengan Islam, berikut ini faktor-faktornya:

1) Faktor perdagangan

2) Faktor perkawinan, yaitu antara pendatang Muslim dengan wanita pribumi pada tahap awal kedatangan Islam

3) Faktor Permusuhan antara orang-orang Islam dan Orang Kristen

4) Faktor politik seperti mundurnya kerajaan Hindu dan Buddha seperti Majapahit dan Sriwijaya

5) Faktor Penghargaan nilai ideologi Islam

Faktor Otoktomi, atau keadaan dimana sesuatu itu dianggap telah ada, sejak purbakala sebagai kepunyaan atau sifat kebudayaan suatu masyarakat. (Muhammad Naquib Al-Attas, 1990:43)

Muhammad Naquib al-Attas di dalam bukunya "Islam dan Sejarah Kebudayaan Melayu" juga menjelaskan bahwa Islam mempunyai pengaruh yang amat besar, mendalam dan meluas di alam Melayu sehingga berjaya mencabut akar umbi pengaruh Hindu dan Buddha. (Muhammad Naquib Al-Attas, 1990:43).

Sebelum masuknya ajaran Islam, masyarakat Melayu memiliki beragam Agama dan kepercayaan seperti Hindu-Buddha dan kepercayaan warisan tradisi Animisme. Kepercayaan Animisme dimaksud adalah satu kepercayaan bahwa setiap benda mempunyai jiwa atau roh yang memiliki kepribadian sendiri. Agama Hindu- Buddha 
masuk ke alam Melayu melalui para pedagang India. Dikutip dari Mohd. Koharuddin dan Mohn. Balwi tentang Peradaban Melayu, h. 87-88.

Animisme sebelum Islam datang ke dunia Melayu, kaum Melayu adalah penganut animisme dan dinamisme yang menjelaskan tentang luasnya praktek-praktek kepercayaan kuno berbasis Melayu. Diantara praktek-praktek tersebut seperti; sihir, tahayul, tabu, perdukunan dalam hubungannya dengan makhluk ghaib seperti, tuyul, setan, jin hantu, dan lain-lain. Sedangkan Hindu dan Budha Masuknya sistem kepercayaan Hindu dan Budha mengganti kepercayaan dinamisme dan animisme pada masyarakat Melayu. Kepercayaan Hindu menawarkan sistem Dewa-dewa dan kasta dengan penjagaan kualitas budaya ada pada penguasa dan tokoh agama. Kepercayaan Budha menawarkan tokoh tunggal sang budha, menawarkan konsep pertapaan dengan penjagaan kualitas budaya ada pada tokoh sentral penguasa.

Kedatangan Islam ke alam Melayu merupakan detik penting dalam mengubah secara keseluruhan pemikiran dan peradaban orang melayu. Walaupun kedatangan dilihat secara evolusi dari sudut penyebarannya tetapi dalam aspek kerohanian atau spiritual agama ini telah merevolusi orang melayu. Artinya ajaran Islam yang mengajarkan ketauhidan (konsep Tauhid) mengubah pandangan dunia Melayu yang tadinya mempercayai dewa-dewa dan mengagung-agungkan raja (menganggap raja sebagai jelmaan

Tuhan "dewaraja" atau wakil Tuhan) telah dimanusiakan menjadi seorang Sultan yang bertugas sebagai Khalifah yang memimpin dan melindungi masyarakat Melayu dan berperan menegakkan pemerintahan Islam di dunia. (Ismail Hamid, 1988:59)

Kedatangan Islam di alam Melayu melahirkan beberapa kerajaan Melayu Islam yang kuat seperti Kerajaan Pasai, Aceh, Patani, Demak dan Melaka hingga negara-negara ini menjadi pusat pengembangan dan keilmuan.

Dalam peradaban melayu terdapat beberapa jenis undangundang yang digunakan sebagai panduan oleh masyarakat Melayu dalam menjalani kehidupan bernegaranya. Sistem undang-undang Melayu yang pernah menjadi pusat ketamaduan Melayu adalah Melaka dan Majapahit. Di Melaka dua teks undang-undangnya yaitu Hukum Kanun Melaka, Undang-undang Laut Melaka dan Undang-undang Pebian Melaka. Sedangkan Undang-undang Majapahit dikenal sebagai Kunta Manawa Dharmasastera.

Masuknya Islam undang-undang Melayu pun terpengaruh seperti Undang-undang Melaka dan Undang-undang Laut Melaka dengan menerapkan hukuman Huddud (Hukuman Islam). Undangundang Islam yang berlandaskan al Qur'an dan Al-sunnah di praktekan oleh kerajaan kesultanan Melayu. Artinya kedatangan Islam yang memberikan pengaruh besar baik dari segi akidah, Undang-Undang dan Pemerintahan Melayu. 


\section{Metode Penelitian}

Metode penelitian yang akan digunakan peneliti adalah penelitian hukum sosiologis,yaitu studi-studi empiris untuk menemukan teori-teori mengenai proses terjadinya dan mengenai proses bekerjanya hukum dalam masyarakat. Berdasarkan karakter metode penelitian ini peneliti menggunakan metode deskriptif analisis secara kualitatif atas peraturan perundang-undangan yang berlaku dikaitan dengan fakta hukum berdasarkan fakta apa adanya yang terjadi di masyarakat lokasi objek penelitian. Dari pembahasan tersebut, ditarik kesimpulan deduktif yaitu penarikan kesimpulan dari yang bersifat umum ke khusus.

\section{Hasil Penelitian dan pembahasan (Pengaruh Agama Islam Dalam Jualbeli Masyarakat Melayu Rokan di Propinsi Riau).}

Masyarakat melayu Rokan berkedudukan di wilayah Rokan Hulu dan Rokan Hilir di Propinsi Riau. Berdasarkan sejarah yang didapat peneliti bahwa jalur masuk pengaruh agama Islam ke masyarakat melayu terdapat dua jalur masuknya yang dominasi dan diikuti dengan aktivitas lainnya.

Fase jalur pertama masuknya pengaruh agama islam pada masyarakat melayu rokan yaitu jalur dakwah ulama yang datang ke wilayah Rokan hulu di daerah Koto tongah. Ulama tersebut datang dan bermukim di wilayah tersebut dengan aktivitas membuka Manosah (madrasah). Kemudian memiliki banyak murid yang belajar agama disana. Diketahui berikutnya ulama tersebut ternyata orang melayu yang belajar ke mekkah.

Fase jalur kedua yaitu melalui kerajaan tambusai yang berada di wilayah rokan hulu merupakan salah satu daerah pemerintahan kerajaan Pagaruyung yang telah melakukan penaklukan daerah kerajaan. Sejak Islam mewarnai kerajaan Pagaruyung di Sumatera Barat dalam tataran politik, raja kemudian mengajak seluruh pengikutnya memeluk Islam. Sesuai dengan teori dalam penyebaran agama islam melalui jalur politik.

Maka kerajaan tambusai sebagai salah satu bagiannya yang terletak di Rokan Hulu pula memeluk agama Islam sebagai bagian dari kerajaan Pagaruyung. Hal ini kemudian mewarnai masyarakat melayu rokan dalam kegiatan sehari-hari. Islam tidak hanya sebagai agama, namun lebih sebagai suatu hal yang mengatur kehidupan. Baik hubungan kepada Tuhan, juga sebagai hubungan antar sesama makhluk, termasuk manusia.

Pengaruh Islam melalui ulama dan kerajaan ini kemudian menjadi warna yang khas sebagai identitas masyarakat melayu. Dari kerajaan pagaruyung kemudian masyarakat melayu mendapatkan pepatah Adat Bersendikan Syara', Syara' Bersendikan Kitabullah hal ini pun bermakna apa apa yang berada dalam lingkungan adat, baik masyarakat, aturan hidup dan sebagainya mestilah berkesesuaian 
dengan syariah yang bersumber dari kitab suci umat Islam yakni AlQur'an.

Selanjutnya kerajaan Siak Sri Indrapura pula mewarnai masyarakat melayu dengan pepatah Adat Menurun, Syara' Mendaki. Hal ini bermakna masuknya Islam telah sampai pada wilayah dataran tinggi pedalaman masyarakat minangkabau dari Siak. Sehingga orang yang ahli dalam agama Islam (Ulama) sejak dulu sampai sekarang masih tetap disebut dengan orang Siak.

Perniagaan merupakan salah satu aktivitas yang sangat diminati oleh masyarakat melayu sejak dahulu hingga saat ini. Sebab masyarakat melayu telah terwarnai dengan nilai Islam yang telah disampaikanUlama dalam Al Qur'an bahwasanya "Allah mengharamkan Riba dan Allah menghalalkan jual beli..." begitu pula Rasul SAW bersabda "bahwa 9 dari 10 pintu rezeki itu ada dalam perniagaan...". Maka hal ini membuat masyarakat melayu yakin dan percaya bahwa rezeki dari Tuhan, maka jalan-jalan apa yang Tuhan telah perintahkan pastilah berkesesuaian.

Dalam perniagaan dengan masyarakat melayu hingga saat ini masih sering terdengar istilah "yo boli" dan yo Jua" saling bersahutan saat terjadinya jual beli. Hal ini kemudian membuat penulis mencoba menguraikan hubungan pengaruh agama Islam dalam aktivitas jual beli masyarakat melayu.

Berdasarkan telaah penulis setelah menemui beberapa sumber data penulis menemukan bahwa:

1. Masyarakat melayu mengetahui hal tersebut merupakan rukun dalam jual beli yakni akad jual beli.

Hal ini penulis temui di beberapa sampel pedagang dan pembeli baik di Kabupaten Rokan Hulu maupun di Kabupaten Rokan Hilir. Namun sebagian besar tidak mampu menjelaskan mengapa hal itu dilakukan saat terjadi jual beli. Mayoritas masyarakat melayu rokan mengatakan bahwa itu kebiasaan turun temurun yang dilakukan oleh orang tua mereka yang juga berprofesi sebagai pedagang. Dan sebagian lagi dari sisi pembeli mereka mendapatkan pemahaman tersebut dari orang tua dan mamak adat yang mengayomi mereka dalam kehidupan.

2. Akad yang digunakan dalam jual beli sebagai pelaksanaan syariah Berdasarkan pandangan pucuk suku dan ulama di kedua kabupaten tempat penulis kunjungi pelaksanaan akad dalam jual beli bukanlah bagian dari adat melayu, namun lebih khusus kepada pelaksanaan perintah agama. Hal ini berkesesuaian dengan karakter seorang "budak melayu" (red. Anak melayu) dalam beragama. Menjalankan agama dalam kehidupan sehari-hari mutlak hukumnya. Sedangkan adat tetaplah dijunjung selama berkesesuaian dengan syariah. Sesuai dengan pepatah yang mengatakan bahwa "Adat bersendikan Syara' Syara' bersendikan Kitabullah".

Masyarakat melayu melalui pucuk suku pula sebenarnya memiliki kebesaran (hak) dalam musyawarahnya untuk menjadikan suatu 
kebiasaan baik menjadi bagian dari adat istiadat (adat mufakat). Terdapat pepatah masyarakat melayu rokan "bulat air karena pematang, Bulat kata karena mufakat".

Berkaitan dengan akad dalam jual beli masyarakat adat, ulama dan pemerintahan masyarakat melayu rokan di ibaratkan "tigo tali sepilin" jika bersepakat menjadikannya bagian dari adat istiadat masyarakat melayu, maka ulama akan mendakwahkan kepada umat islam, pucuk suku mengesahkan sebagai bagian dari adat dan kepala pemerintahan menghimbau masyarakat mematuhinya.

3. Guna mendapatkan keberkahan mengikuti perintah agama.

Masyarakat melayu rokan yakin saat mengikuti perintah agama akan membawa keberkahan. Nilai ini yang difahami oleh masyarakat melayu rokan berabad-abad lamanya sebagai implikasi dari pemahaman tauhid kepada Tuhan. Keberkahan bukanlah sesuatu yang dapat dilihat mata secara materiil, namun bagi masyarakat melayu keberkahan lebih berarti dalam kehidupan di dunia. Keyakinan ini yang membuat mengapa masyarakat melayu rokan terus mengamalkan akad dalam jual beli. Walaupun semakin kompleksitasnya hidup bermasyarakat dan heterogennya masyarakat saat ini tidak menyurutkan aktivitas guna meraih keberkahan.

Berdasarkan data hasil penyelidikan penulis dalam hal akad jual beli, bagi masyarakat melayu rokan agama Islam memiliki kedudukan yang sangat penting dan mendasar sebagai identitas kemelayuan pribadi. Sebab pelaksanaan perintah agama bagi masyarakat melayu tidak sekedar menjalankan rutinitas semata, bahkan menjalankan perintah agama adalah sebagai keseluruhan aktivitas sehari-hari. Karena agama Islam adalah agama peradaban dan tata perilaku.

\section{Kesimpulan}

Berdasarkan hasil penelitian dan pembahasan uraian diatas, peneliti mendapatkan simpulan berupa Pengaruh Agama Islam bagi adat melayu membawa kepada fase melayu keemasan, dimana nilai-nilai syariah yang dijalankan oleh masyarakat melayu rokan memberikan kepercayaan diri baik bagi pribadi maupun secara kelompok. Hal ini menguatkan hubungan kekerabatan melayu yang tidak mengenal batas territorial, terlebih budaya melayu ini tidak hanya di Propinsi Riau, namun hamper keseluruhan daratan bumi nusantara. Sama seperti pemahaman tauhid (aqidah) agama Islam yang juga tidak mengenal batas dalam persaudaraan umat Islam. Terkait hal akad jualbeli, bagi masyarakat melayu rokan agama Islam memiliki kedudukan yang sangat penting dan mendasar sebagai identitas kemelayuan pribadi. Sebab pelaksanaan perintah agama bagi masyarakat melayu tidak sekedar menjalankan rutinitas semata, bahkan menjalankan perintah agama adalah sebagai keseluruhan aktivitas sehari-hari. Sehingga masyarakat melayu Rokan tetap menempatkan syariah di tempat semestinya yaitu syariah, serta adat 
tetap terjaga tanpa adanya gangguan dari aktivitas jualbeli dengan menggunakan akad jualbeli Karena agama Islam adalah agama peradaban dan tata perilaku.

\section{DAFTAR PUSTAKA}

A. Samad Ahmad (2013). Sulalatus Salatin. Kuala Lumpur: Dewan Bahasa dan Pustaka.

Ali Akbar Dt. Pangeran (2006). Islam dan Adat Andiko 44 Melayu Riau. Pekanbaru: Alaf Riau.

Beckford J.A 2001. Social movement as free-floating religious phenomena. In The Blackwell Companion to Sociology of Religion. ed. R.K Fenn. Oxford: Blackwell Publishers.

Effendy Tennas. 2010. Kearifan Pemikiran Melayu. Pemko Kota Pekanbaru - Universiti Malaya. Yayasan Tennas Effendy. Pekanbaru

Effendy. Tennas 2005. Tegak Menjaga Tuah Duduk Memelihara Marwah. Balai Kajian dan Pengembangan Budaya Melayu. Yogyakarta.

Effendy. Tennas 2009. Bujang Tan Domang. Yayasan Obor Indonesia. Jakarta.

Gullick, J. M. (1978). Sistem Politik Bumiputera Tanah Melayu Barat. Kuala Lumpur : Dewan Bahasa dan Pustaka.

Hendrik Makmur k (ed) . 2005. Tegak Menjaga Tuah. Duduk Memelihara Marwah. Mengenal sosok. Pemikiran dan Pengabdian H. Tennas Effendy. Balai Kajian dan Pengembangan Budaya Melayu. Yogyakarta

Koentjaraningrat.2007. Masyarakat Melayu dan Budaya Melayu dalam Perubahan, Yogyakarta: Balai Pengkajian dan Pengembangan Budaya Melayu.

Miles. M.B dan Huberman A.M. 1992. Analisis Data Kualitatif. Jakarta : Universitas Indonesia

Monograf Sejarah Budaya Melayu tingkat Dasar, LAMR Luhak Rambah.

Muhammad Yusoff Hashim (1989). Kesultanan Melayu Melaka. Kuala Lumpur: Dewan Bahasa dan Pustaka. 